\title{
ECONOMIC EFFECTS OF THE DIGITAL DIVIDE ON PENSIONERS IN GERMANY REGARDING RETAIL BANKING SERVICES
}

\author{
Oliver Sievering ${ }^{1}$
}

\begin{abstract}
:
In the recent two decades, many service sector companies like banks altered their services and fees towards a regime whereby customers either bank online on their own or face comparatively high fees. The current phase of interest rates close to zero or even below - due to the euro crisis enhances this trend. Many commercial banks in Germany have increased their fees for current accounts significantly, the common "free current account" policy has come more or less to an end. Many of the pensioners - in Germany there are more than 20 million retirees - are affected, because their pensions are quite low and they are not familiar with doing their banking the online way. This paper analyzes the situation based upon statistical data and develops other fee structures which are more just, from a social point of view, than burdening the elderly with low incomes.
\end{abstract}

\section{Economic crisis and the role of the $\mathrm{ECB}$}

In the autumn of 2008, the financial crisis reached a peak, when Lehman Brothers Holdings Inc., one of the biggest American investment banks, had to file for bankruptcy. There was cause for concern that many banks in Europe could file for bankruptcy too. The European states were quarrelling about how to meet the crisis, which (fiscal) measures should be taken in order to save European banks and how to boost the European economy again. In contrast to the European states, the European central bank (ECB), acted swiftly and put into place a very accommodating monetary policy. The ECB was, however, also criticized for this. The main allegation was and furthermore still is, that the main objective of the ECB would be jeopardized.

The primary objective of the ECB is to maintain price stability, as defined in Article 127(1) of the Treaty on European Union: "Without prejudice to the objective of price stability, the ECB shall support the general economic policies in the Union with a view to contributing to the achievement of the objectives of the Union as laid down in Article 3 of the Treaty on European Union."

Article 3 (3) of the Treaty on European Union: "The Union shall establish an internal market. It shall work for the sustainable development of Europe based on balanced economic growth and price stability, a highly competitive social market economy, aiming at full employment and social progress and an high level of protection and improvement of the quality of the environment. It shall promote scientific and technological advance."

In 1998 the Governing Council of the ECB announced the quantitative definition of price stability: "Price stability shall be defined as a year-on-year increase in the Harmonised Index of Consumer Prices (HICP) for the euro area of below 2\%. Price stability is to be maintained over the medium term". The Governing Council further clarified that, within the definition, it aims to maintain

\footnotetext{
1 Professor, University of Public Administration and Finance Ludwigsburg, Reuteallee 36, 71634 Ludwigsburg, Germany. Email: sievering@hs-ludwigsburg.de
} 
inflation rates "below, but close to, $2 \%$ over the medium term". By referring to "an increase in the HICP of below but close to $2 \%$ " the definition makes clear that not only inflation above $2 \%$, but also deflation is inconsistent with price stability. In the pursuit of price stability, the Governing Council's explicit aim is to maintain the inflation rate at a level below, but close to, $2 \%$. [1]

In the last few years the inflation rate in the euro area was and is, well below the $2 \%$ (see table 1 ). The setting of an objective for monetary policy in a monetary union also takes into account the existence of inflation differences across regions in the union which operate at different stages of economic development. Inflation differences between the euro area countries are moderate.

\begin{tabular}{|l|l|}
\hline year & Inflation rate (euro area) \\
\hline 2013 & $1,3 \%$ \\
\hline 2014 & $0,4 \%$ \\
\hline 2015 & $0,0 \%$ \\
\hline 2016 & $0,2 \%$ \\
\hline
\end{tabular}

Table 1: Rate of inflation in the euro area [2]

Without prejudice to the primary objective of price stability, the ECB has to support the general economy. The rate of inflation is low. So, according to Article 3, the ECB shall "support the general economic policies in the Union with a view to contributing to the achievement of the objectives of the Union" which include, inter alia, "full employment" and "balanced economic growth". A closer look at the statistics indicates a relatively high unemployment rate and a weak economic growth in the euro area.

Due to the financial and economic crisis, the number of unemployed persons in the euro area has risen considerably. In 2007, the unemployment rate in the euro area was still at $7.4 \%$. It rose to $12.0 \%$ in 2013 and then declined to $10.9 \%$ in 2015 . The following countries have particularly high unemployment rates (2015): Greece (24.9\%), Spain (22.1\%), Portugal (12.6\%) and Slovakia (11.5\%). In contrast Germany (4.6\%), Malta (5.4\%) and Austria (5.7\%) have particularly low unemployment rates. [3] The gross domestic product (GDP) in the euro area has risen only slightly in recent years: In 2012 and 2013 the rate of growth was even negative: $2012(-0.9 \%), 2013:(-0.3$ $\%), 2014:(+1.2 \%)$ and 2015: $(+2.0 \%)$. Greece has recorded significant growth slumps in the year $2011(-9.1 \%)$ and $2012(-7.3 \%)$. [4]

\section{Important instruments of ECB}

In order to achieve the objectives mentioned above, the ECB has at its disposal a set of monetary policy instruments, in particular it conducts open market operations and standing facilities.

\subsection{Open market operations}

Open market operations play the most important role in the monetary policy of the ECB. They are used for steering interest rates and for managing the liquidity situation in the market. With these operations the ECB lends funds to commercial banks. The ECB can set the main conditions: the interest rate and the amount of money. Since October 2008 and the collapse of Lehman Brothers, a full allotment procedure was introduced. No longer is allocation volume fixed in advance. Each commercial bank receives the amount of "base money" it needs. Furthermore the ECB reduced the main interest rate over the years to $0 \%$ in 2016, an historically low level. (see table 2) 


\subsection{Standing facilities}

For the purpose of controlling short-term interest rates in the money market, the euro system also offers two standing facilities to commercial banks: the marginal lending facility and the deposit facility. Both facilities have an overnight maturity and are available to commercial banks on their own initiative. [5]

Commercial banks can use the "marginal lending facility" to obtain overnight liquidity from the national central banks for eligible assets. There are no credit limits or other restrictions on commercial banks access to the facility apart from the requirement to present sufficient underlying assets. The interest rate on the marginal lending facility normally provides a ceiling for the overnight market interest rate.

Commercial banks can use the "deposit facility" to make overnight deposits with the national central banks. There are no deposit limits or other restrictions. The interest rate on the deposit facility normally provides a floor for the overnight market interest rate.

As the overall amounts requested by banks were higher than the liquidity needs of the banking system during this period, the excess liquidity was placed in the deposit facility by many commercial banks. However, the ECB does not want the excess liquidity to be re-invested in the deposit facility. The ECB would prefer to see this money lent to companies and to individuals in order to stimulate the economy. The ECB did not want to forbid the use of the deposit facility but has made this instrument unattractive. For the first time in history, the ECB set a negative (!) interest rate. The deposit rate currently stands at $-0.4 \%$. Now, commercial banks must pay an interest rate for placing short term money at the ECB.

The interest rate on the marginal lending facility is normally substantially higher than the corresponding money market rate and the interest rate on the deposit facility is normally substantially lower than the money market rate. By setting the rates on the standing facilities, the Governing Council effectively determines the band within which the overnight money market rate can fluctuate.

\begin{tabular}{|l|l|l|l|}
\hline Selected years & Main interest rate & deposit facility rate & $\begin{array}{l}\text { marginal lending facility } \\
\text { rate }\end{array}$ \\
\hline 31.12 .2007 & $4,0 \%$ & $3,0 \%$ & $5,0 \%$ \\
\hline 31.12 .2008 & $2,5 \%$ & $2,0 \%$ & $3,0 \%$ \\
\hline 31.12 .2009 & $1,0 \%$ & $0,25 \%$ & $1,75 \%$ \\
\hline 31.12 .2013 & $0,25 \%$ & $0,0 \%$ & $0,75 \%$ \\
\hline 31.12 .2014 & $0,05 \%$ & $-0,2 \%$ & $0,3 \%$ \\
\hline 31.12 .2016 & $0,0 \%$ & $-0,4 \%$ & $0,25 \%$ \\
\hline
\end{tabular}

Table 2: Development of the ECB key interest rates since 2007 [6]

Table 2 shows the development of key interest rates since 2007. The general decline in interest rates is noticeable. Also noticeable is the spread between the interest rates, it becomes much closer, from $3,0 \%$ and $5,0 \%$ in 2007 to $-0,4 \%$ and $0,25 \%$ in 2016 .

\subsection{Transmission mechanism of monetary policy}

With low interest rates, the ECB is pursuing certain perceptions of its effects. The process through which monetary policy decisions affect the economy is known as the transmission mechanism of monetary policy. It is a (long) chain of causes and effects linking monetary policy decisions with 
real economic data. The chain starts with a change in the official interest rates set by the ECB. [7] Changes in money market rates in turn affect other interest rates, albeit to varying degrees. Changes in money market rates also have an impact on interest rates set by banks on short term loans and deposits. It affects savings, spending and investment decisions of companies and households. Lower interest rates tend to make it more attractive for households and companies to take out loans in order to finance their consumption or investment. This will increase GNP and the unemployment rate can be reduced. This transmission process is, however, very long and its effects are uncertain. In southern European countries like Greece, the transmission process hardly functions at all.

Despite the very accommodating monetary policy, the sum of money in circulation has risen sharply and interest rates have fallen to an historically low level - Greece fell into a long and deep depression. Furthermore, the accommodating monetary policy has negative side effects and creates new problems in other countries like in Germany. The economic situation in Germany is good but, due to the low net interest spread, banks now earn less money. Furthermore the depositors hardly earn any interest when they put their money into the bank. It also has negative effects on pension plans of individuals.

The longer the period of low interest rates lasts, due to the economic situation in many countries in southern Europe, the more serious are the consequences for banks and for depositors. Because of their bread and butter business model, of lending and saving more and living on the net interest spread, more or less collapsed, many banks find themselves obliged to raise their fees.

\section{Digitalisation}

In addition to the persistent reduction of the margins, there is another huge challenge for banks: the digitalisation. The increasing use of digital formats should have a positive impact on banks' earnings situation by cutting costs. With digitalisation, profitability can be increased in the long term. In the short term, however, this initially entails higher costs. Financial institutions firstly must invest massively in new digital facilities. They have little choice. They must be prepared to see their competitive position deteriorate in the medium term, as lower prices will reduce margins and new digital offerings will cannibalize traditional products and services.

Most institutes have seen that interaction with customers is fundamentally changing. So many digital initiatives have already been implemented. A lot of banks produced digital applications, socalled "apps", which make it easier for the customers to do their banking transactions via smartphones or tablet computers. [8] Many institutions use the challenge of digitalisation in order to reduce their branch network. They can streamline their processes, sharpen their range of services and align them increasingly to the needs of their customers as well as tap into new revenue potential by deepening the customer relationship. They have brought their technologically competent clientele onto their website to try to replace even fully automated stores with automated kiosks. The nature of communication and the analysis of investment decisions are changing. Before visiting a branch, the customers more often use the Internet to find out about the products and services, compare conditions, or obtain opinions from other consumers.

Despite the comfortable use of digitalisation, one thing remains very important for customers: The basic need for customers to save their money in a safe environment. Another important aspect for customer and banks is that of the charges. It is necessary to create a transparent and uniform price structure across all off line and online channels. Currently, many banks are still promoting low cost online fees, i.e. for current accounts, in order to motivate customers to make transactions online. If 
financial institutions want to stick to a different price strategy, they must be able to justify convincingly this differentiation and the differences in performance behind it. Pricing should also take into account customer behavior.

\section{Payment behavior}

In several surveys the German Bundesbank has stated that people in Germany are changing their behavior for paying for goods and services, but only slowly. Changes in this area are not yet revolutionary but evolutionary and in small steps. Cash is still the most important payment medium. $53 \%$ of all transactions are paid with cash. Half of the customers are fixed in their choice of payment instrument: $33 \%$ of respondents always pay cash, $17 \%$ pay cash wherever it is possible. For payments up to 50 euro, cash is still by far the most frequently used method of payment. In principle, predefined behavior can make it difficult for innovation in payment transactions. The age of the interviewees still has a significant influence on their payment behavior. Retirees especially have a high preference for cash payment. Nearly half of the retirees interviewed stated that their payments are made exclusively with cash. The pure cash payers tend to be amongst the older and even the less well off, whereas the non cash payers are more likely to be recruited from younger and higher income respondents. The most important reason why every third person pays only cash is the feeling of better spending control. [9]

Mobile and contactless payment methods are still rarely used, in particular due to a lack of consumer acceptance in the retail trade but also due to inadequate consumer equipment with insufficient contactless payment cards and mobile payment methods being available. More and more goods and services are purchased online. This development basically promotes the use of non cash payment instruments.

A representative survey, conducted by the German Banking Association in 2014, concluded that $65 \%$ of people aged $18-59$ use online banking. Only $33 \%$ of the seniors over 60 years, however, are using online banking. [10] So $67 \%$ of the seniors do not use online banking. According to the current study of Initiative D21, some 70 percent of all over 70s in Germany have no Internet access. [11] Thus they are practically excluded from the use of many facilities. This phenomenon is particularly widespread amongst the users of banking products. Many offers are only available online. The Sparkasse Berlin, for example, offers deposit bank accounts only online. Online banking seems to ignore the customer needs of the older people. Indeed, banks are suffering from the current low interest rate and are therefore striving to reduce their personnel costs. Critics say, however, that saving personnel costs must not lead to people without internet access being disconnected or disadvantaged, but they are disadvantaged.

\section{Fees of current accounts: selected banks in Germany}

According to "Finanztest", a respected consumer magazine in Germany, there were only 24 free current accounts in more than 200 current account models available at approximately one hundred banks at the end of 2016. This includes all online transactions, with the use of debit card free of charge and no other conditions having to be fulfilled. Amongst them there are only two affiliated banks, all others are online banks. [12]

Banks have increased their fees for current accounts, or linked them to some other conditions such as the certain receipt of a sum of money every month. The intense competition, the advancing digitalisation and the sustained low level of interest rates, coupled with low interest rate margins, 
increases the pressure on banks to reconsider their cost structure. There are a lot of banks with very different current account models. For analyzing the fees payable for current accounts, the author has selected the three banks with the most branches in Germany: Deutsche Bank: 2,984 branches, Commerzbank: 1,530 branches and Postbank: 1,092 branches. They also each have millions of customers.

\subsection{Current account fees: Postbank (14 million customers)}

The Postbank is one of the largest banks in Germany. In November 2016, the Postbank launched a new charging system for its various current account models. Dependant upon usage behavior and receipt of money, they differ in price and performance. [13]

The "Postbank Giro start direct" is a mainly free of charge current account for customers up to 22 years of age. The reason is obvious; it is a strategy to tie young people to the Postbank. It is also assumed that young customers are doing their transactions online. For off line transactions one has to pay 0.99 each. For persons older than 22 years there is the "Postbank Konto - Giro direct". Here one has to pay a fee for the current account of 1.90 euro per month. It is a tariff for people doing many transactions online. For telephone banking one has to pay 1.50 euro per transaction and also to pay 1.50 for off line. For those persons who wish to do their transactions digitally, but also want personal contact, there exists the "Postbank Giro Plus". Here one has to pay a basic fee of 3.90 euro and 0.99 euro for each transaction off line. The so called comfort account "Postbank Giro extra plus" is "for all who require additional extras included". In this case one does not have to pay for each transaction off line. One does have to pay a fee of 9.90 euro per month but, starting with receipt of money of more than 3,000 euro per month, this account is free of charge. So this is a costly alternative if one does not receive more than 3,000 euro per month. Postbank argues that this alternative is very personnel cost intensive. This alternative is preferred by many retirees because they use online banking less frequently.

\subsection{Current account fees: "Deutsche Bank" (10 million customers) [14]}

The system of current account fees of the Deutsche Bank is similar to the system of the Postbank. The Postbank is a subsidiary of the "Deutsche Bank".

The "JungeKonto" is especially for young customers. The account is free of charge for pupils and students. The main goal of this price policy is to gain customer loyalty. For credits made by credit transfer form, or made by a bank transfer and placed via customer service hotline staff, or at a Deutsche Bank branch, one has to pay 1.50 euro, if the account holder is older than 18 years. The advertising of the "Deutsche Bank" claims that this current account model is an account for persons who prefer "modern and convenient online and mobile banking". The "AKTIVKonto" is for customers who also prefer online and mobile banking. The monthly charge is 4.99 euro. Setting up and amending standing orders, via customer service hotline staff, costs 1.50 euro. For cheques drawn and presented, one has to pay 1.50 euro. For credits made by credit transfer form, or made by a bank transfer and placed via customer service hotline staff, or at a Deutsche Bank branch, one has also to pay 1.50 euro. The monthly charge for the „db BestKonto“ is 9.99 euro, almost all services being included. 


\subsection{Current account fees: "Commerzbank" (more than 11 mio. customers) [15]}

The system of fees of the Commerzbank is quite similar to the current account systems of the Postbank and the Deutsche Bank.

The „StartKonto“, a current account for young people, is free of charge. For each cheque drawn and presented one has to pay 1.50 euro. If one selects the „PremiumKonto“, one has to pay a monthly charge of 9.90 euro, the main services being included. If one selects the "0-euro-account" one has to pay 9.90 euro per month but, if one receives 1,200 euro and more per month, this current account is free of charge. One does, however, have to pay 1.50 euro for every credit made by means of a credit transfer form and for every telephone banking transaction, 1.50 euro too. The monthly charge for the "AktivKonto" is 7.90 euro. It is a little cheaper than the "PremiumKonto", but for telephone banking, one has to pay 1.50 euro per transaction. Another current account model is the „BasisKonto". Here one has to pay 6.90 Euro each month. For cheques drawn and presented one has to pay 1.50 euro per transaction and for telephone banking 1.50 for each remittance.

\subsection{Summary and consequences of the current account models}

In recent years many banks have increased their current account charges. The strategy behind the new current account charging systems is obvious. If the customers are using online banking, the current account fees are inexpensive, often they are free of charge. If the customers do not use online banking, then they have to pay high fees. It is interesting and conspicuous that all three merchant banks examined offer an "all inclusive current account model" with a monthly fee about 9,90 euro: Postbank: 9.90 euro, Deutsche Bank: 9.99 and Commerzbank: 9.90 euro. Only $33 \%$ of people older than 60 years are using online banking. So most of the older people cannot, or do not, use online banking. As a result, they often choose an expensive current account model. (Unfortunately there is no official data on this but interviews with three bank employees confirm that retirees very often choose "all inclusive models".)

Around 20 million Germans lived on a pension in 2015. Male pensioners received, on average, a pension of 1,130 euros whilst female pensioners received an average of 653 euros (gross pension). [16] There are great differences between the genders, the average pensions of women are significantly lower than men's pensions. It should be noted that these are average figures, but the data shows, retirees receive much lower income than full time employees. Furthermore retirees often select an expensive "offline current account".

\section{Disadvantage of the seniors}

Pensioners often earn considerably less than full time employees, they often have no Internet and they more often select more costly, personnel intensive, current accounts. Banks have significantly increased their fees for current accounts in recent months. They argue that they "must" do this because the interest rate margin is very low and the general interest rate is also very low. The Deposit Facility even has a negative interest rate of $-0.4 \%$, this is the main argument for increasing the fees.

So the question arises: What would be the impact, were the commercial banks not to have increased their fees in this manner but, instead, passed this negative interest rate $(-0,4 \%)$ on to their customers? We will determine the amount of the "penalties" if retirees receive a certain receipt of 
money into their account and this money remains on the current account for an average of one month. How much would be the "penalty interest"?

The formula for the calculation of interest is:

$\mathrm{I}=\mathrm{M} * \mathrm{i} * 30 / 360$

$\mathrm{I}=$ Interest, $\mathrm{M}=$ Money in the current account. In Germany you calculate 360 days for the whole year and 30 days for each month.

Unfortunately, there is no public data on how high the volume of money in the current accounts of retirees is, so some comparative calculations, with several assumptions, are made.

Firstly: You have different receipts of money and it is assumed, that this money is on the current account for one month. If you have a receipt of money of 1,130 Euros monthly (average male pension), then you would have to pay 0,38 euros, if the negative deposit rate would be passed on "one to one" to the customer. (see table 3) Now we compare it to an "all inclusive current account" which costs 9.90 euro per month. The (nearly) accurate fees are, of Postbank: 9,90 euro, Commerzbank: 9,90 euro and Deutsche Bank: 9,99 euro. So the fee is significantly higher than in the situation in which the negative deposit rate would be passed " 1 to 1 " to the customer. In the case that the person is a customer of the Postbank, then the fee is 0 euro, if receipts are 3,000 Euro per month. If you receive money of 29,700 (!) euros per month, then you have to pay 9.90 euros if the negative rate were to be passed on, one to one, to the customer - an amount of money which hardly any pensioner receives.

\begin{tabular}{|l|l|l|}
\hline Receipt of money (per month) & Negative deposit rate: $-0,04 \%$ & Current account fee \\
\hline 100 euro & 0.03 euro & 9.90 euro \\
\hline 200 euro & 0.07 euro & 9.90 euro \\
\hline 500 euro & 0.17 euro & 9.90 euro \\
\hline 1,000 euro & 0.33 euro & 9.90 euro \\
\hline 1,130 euro & 0.38 euro & 9.90 euro \\
\hline 2,000 euro & 0.67 euro & 9.90 euro \\
\hline 2,999 euro & 1 euro (nearly) & 9.90 euro \\
\hline 3,000 euro & 1.00 euro & 0 euro \\
\hline 29,700 euro & 9.90 euro & 0 euro \\
\hline
\end{tabular}

Table 3: Comparison: Negative deposit rate and actual Postbank fee "Postbank Giro extra plus"

The question arises whether or not it is unrealistic to assume that all of the money is in the current account for one month. The core statements do not change if some other assumptions are made. Second assumption: The pensioner receives the money evenly over the entire month. Then the current fee is still 9.90 euro. The average balance on the current account in this case, as mentioned above, is then $1,130 \div 2$ euro $=565$ euro and the negative deposit charge would be 0.19 euro. The actual fee (9.90), is higher. Furthermore it seems unfair for retirees. Similar is the situation if the customer draws the entire money on the day of receipt (third assumption) then he would be charged, like the deposit rate, and has to pay 0.01 euro. The Postbank fee is 9.90 euro.

\section{Result}

Due to the severe economic situation in many southern countries the ECB has dropped the interest rates to an historically low level. The deposit facility rate now is negative $(-0,4 \%)$ ! The margins are very low. So a lot of commercial banks have increased their current account fees, especially for those customers who make their bank transactions off line. A lot of retirees do not use the internet 
and they receive only low pensions. The increase in the accounting charges by many banks, in recent months, seems therefore to be unfair for them. They are burdened with higher fees. A charge in the form of an amount of negative interest would be a much more favorable solution for the retirees. Due to the fact that they earn not much money and that they rarely use the Internet, they are disadvantaged.

\section{References}

[1] European Central Bank, The Monetary Policy of the ECB, 2011, p. 64, Source: https:// www.ecb .europa .eu/pub/pdf/other/monetarypolicy2011en.pdf

[2] Eurostat, http://ec.europa.eu/eurostat/tgm/table.do?tab=table\&init=1\&language $=$ de $\&$ pcode $=$ tec00118\&plugin $=1$

[3] Eurostat, http://ec.europa.eu/eurostat/tgm/table.do?tab=table\&plugin=1\&language=de\&pcode $=$ tsdec 450

[4] Eurostat, http://ec.europa.eu/eurostat/tgm/table.do?tab=table\&init=1\&plugin=1\&language $=\mathrm{de} \& \mathrm{pcode}=\mathrm{tec} 00115$

[5] European Central Bank, The Monetary Policy of the ECB, 2011, p. 108, Source: https://www. ecb.europa.eu/pub/pdf/other/monetarypolicy2011en.pdf

[6] Key interest rates, Source: Bundesbank,https://www.bundesbank.de/Redaktion/DE/Down loads/Statistiken/Geld_Und_Kapitalmaerkte/Zinssaetze_Renditen/S510TTEZBZINS.pdf?_b1 $\mathrm{ob}=$ publicationFile

[7] European Central Bank, The Monetary Policy of the ECB, 2011, pp. 58, Source: https://www. ecb.europa.eu/pub/pdf/other/monetarypolicy2011en.pdf (S. 58ff)

[8] Bain \& Company; Retail-banking, Die digitale Herausforderung, 2012, p. 8, Source: http:// www.bain.de/Images/Retail_Banking_II_Digitalisierung_ES.pdf

[9] Bundesbank, Zahlungsverhalten in Deutschland 2014, Dritte Studie über die Verwendung von Bargeld und unbaren Zahlungsinstrumenten, p. 26 ff., Source: https://www.bundesbank.de/ Redaktion/DE/Downloads/Veroeffentlichungen/Studien/zahlungsverhalten_in_deutschland_2 014.pdf?__blob=publicationFile

[10] Bankenverband deutscher Banken, Seniorenstudie 2014 Finanzkultur der älteren Generation, p. 29, Source: https://bankenverband.de/media/files/Seniorenstudie_.pdf

[11] GfK Marktforschung, Nürnberg, im Auftrag des Bundesverbands deutscher Banken Initiative D21 2016, D21 - Digital - Index, p. 25, Source: https://www.bertelsmann-stiftung.de/ fileadmin/files/BSt/Publikationen/GrauePublikationen/D21_Index2016_WEB-final.pdf

[12] Source: focus, http://www.focus.de/finanzen/banken/finanztest-diese-25-girokonten-sindnoch-kostenlos_id_5974345.htmlMany

[13] Postbank offers, Source:https://www.postbank.de/privatkunden/docs/Kontovergleich.pdf 
[14] Deutsche Bank, List of prices and services of Deutsche Bank, Source: https:/www.deutschebank.de/pfb/data/docs/ser-konditionen_preise-preisaushang.pdf

[15] Commerzbank, Preis- und Leistungsverzeichnis, Source: https://www.commerzbank.de/ portal/media/efw-dokumente/preis_leistungsverzeichnis.pdf

[16] Rentenversicherung in Zahlen 2016, Deutsche Rentenversicherung, Source: http://www. deutscherentenversicherung.de/cae/servlet/contentblob/238692/publicationFile/61815/ 01_rv_in_zahlen_2013.pdf 